\title{
Comparison of Linear and Nonlinear Seismic Behavior of 2D and 3D RC Buildings
}

\author{
Esra Özer ${ }^{a^{*}}$, Muhammet Kamal ${ }^{b}$, Mehmet Inel $^{c}$ \\ Pamukkale University, Faculty of Engineering, Civil Engineering Department \\ *E-mail address: esrao@pau.edu.tr \\ ORCID numbers of authors: \\ 0000-0002-7778-0119 $, 0000-0001-6648-2346^{b}, 0000-0002-8323-259 X^{c}$
}

Received date: August 2017

Accepted date: December 2017

\begin{abstract}
This study compared displacement demands obtained from linear and nonlinear time history analyses of $2 D$ and $3 D$ models to investigate how 2D models reflect 3-D models. Estimates of $2 D$ and $3 D$ linear and $2 D$ nonlinear models were also compared to that of $3 D$ nonlinear model to visualize success of linear and $2 D$ nonlinear models in seismic displacement estimates of RC buildings. A total of 288 dynamic analyses were performed with 12 different records taking into account two principal directions of 10-, 15- and 20-storey buildings. Outcomes of the current study imply that 2D representation of $3 D$ models needs careful modelling. Buildings are usually designed according to related earthquake code considering both gravity and seismic loads. Then, an interior frame is used for $2 D$ modelling. The periods of $3 D$ and $2 D$ models need to be closer for proper representation. Another observation is that the $2 D$ linear elastic models do not properly represent the $3 D$ nonlinear models. Thus, it is recommended to use $3 D$ models when linear modelling is preferred. Since 2D nonlinear models represent reasonably well their 3D nonlinear ones, $2 D$ modelling can be preferred for buildings with no irregularity due to extensive labor and time required for $3 D$ nonlinear models.
\end{abstract}

Keywords: displacement demands, 2D and 3D frame models, linear and nonlinear analyses, time history analysis, ground motions with forward directivity effects.

\section{Introduction}

Displacement demand estimates of building stock in earthquake prone countries are essential for seismic performance evaluation. Static or dynamic analysis can be used in estimating displacement demands of structures. Although nonlinear time history analysis provides precise estimates, it may cause labor and time loss. Therefore static (pushover) analyses or nonlinear time-history analyses of "equivalent" SDOF system reflecting 3D models are preferred for their simplicity in estimating displacement demands of structures. Also, linear time history analyses are used for estimates of seismic displacement demands.

In this study, three structures selected as 10-, 15- and 20-storey are considered to represent mid-rise reinforced concrete buildings. These buildings are modelled as three dimensional (3D) frame elements without shear walls in SAP2000 [1]. In addition, two dimensional (2D) models were derived from the interior frames in two principal directions of 3D models. In total, 27 models as three $3 \mathrm{D}$ and six 2D models for each building were created. 12 past earthquakes records with forward directivity are selected for using linear and nonlinear time-history analysis. In part 1 of the study, displacement demands obtained from linear and nonlinear time history analyses of 2D and 3D 
models were compared to investigate how 2D models reflect 3-D models. In part 2 of the study, the estimates of 2D and 3D linear and 2D nonlinear models were compared to that of 3D nonlinear model in order to visualize success of linear and 2D nonlinear models in seismic displacement estimates of RC buildings. A total of 288 dynamic analyses were performed with 12 different earthquakes records taking into account the two principal directions of 10-, 15- and 20-storey buildings. The outcomes and findings of the study are useful to better understand the consequences and issues in implication of 2D and 3D linear and 2D nonlinear models.

\section{Description of buildings and modeling approach}

10, 15 and 20-storey reinforced concrete buildings were taken into consideration as mid-rise buildings for this study. Building models have double symmetry axis; consists of a typical beamcolumn RC frame system with no shear walls. The plan view of the 3D models and the $2 \mathrm{D}$ models derived from the inner axes of this model were given in Fig 1. The selected buildings are designed according to modern Turkish Earthquake Code (TEC-2007) considering both gravity and seismic loads [2]. A design ground acceleration of $0.40 \mathrm{~g}$ assuming the highest seismicity zone and soil class $\mathrm{Z} 3$ that is similar to the class $\mathrm{C}$ soil of FEMA-356 is assumed [3]. Compressive concrete strength value of $35 \mathrm{MPa}$ is considered while the yield strength of both longitudinal and transverse reinforcement is assumed to be $420 \mathrm{MPa}$. The period values of the dominant vibration mode of the models are given in Table 1. Nonlinear models have been developed to investigate how the linear models reflect the nonlinear models. Nonlinear behavior was achieved through plastic hinges defined at both ends of beams and columns. The plastic hinge length in the critical sections was calculated as half ( $\mathrm{h} / 2$ ) of the cross section height in the relevant direction as specified in TEC-2007 for the Mander confined concrete model [4-5]. The software SEMAp is used for moment-curvature analyses of $\mathrm{RC}$ sections reflecting their material properties longitudinal and transverse steel content, and axial load level of the critical sections [6]. Using the curvature values obtained as a result of the analyses, the rotation values of the critical points given in Figure 2 were calculated [7]. SAP2000 is used for linear and nonlinear analyses [1]. Newmark mean acceleration method is used for linear and nonlinear time history analyses in SAP2000. Effective stiffness values for all linear and nonlinear models are obtained per 2007 Turkish Earthquake Code; 0.4EI for beams and values between 0.4EI and 0.8 EI depending on axial load level for column elements $[2,8,9]$

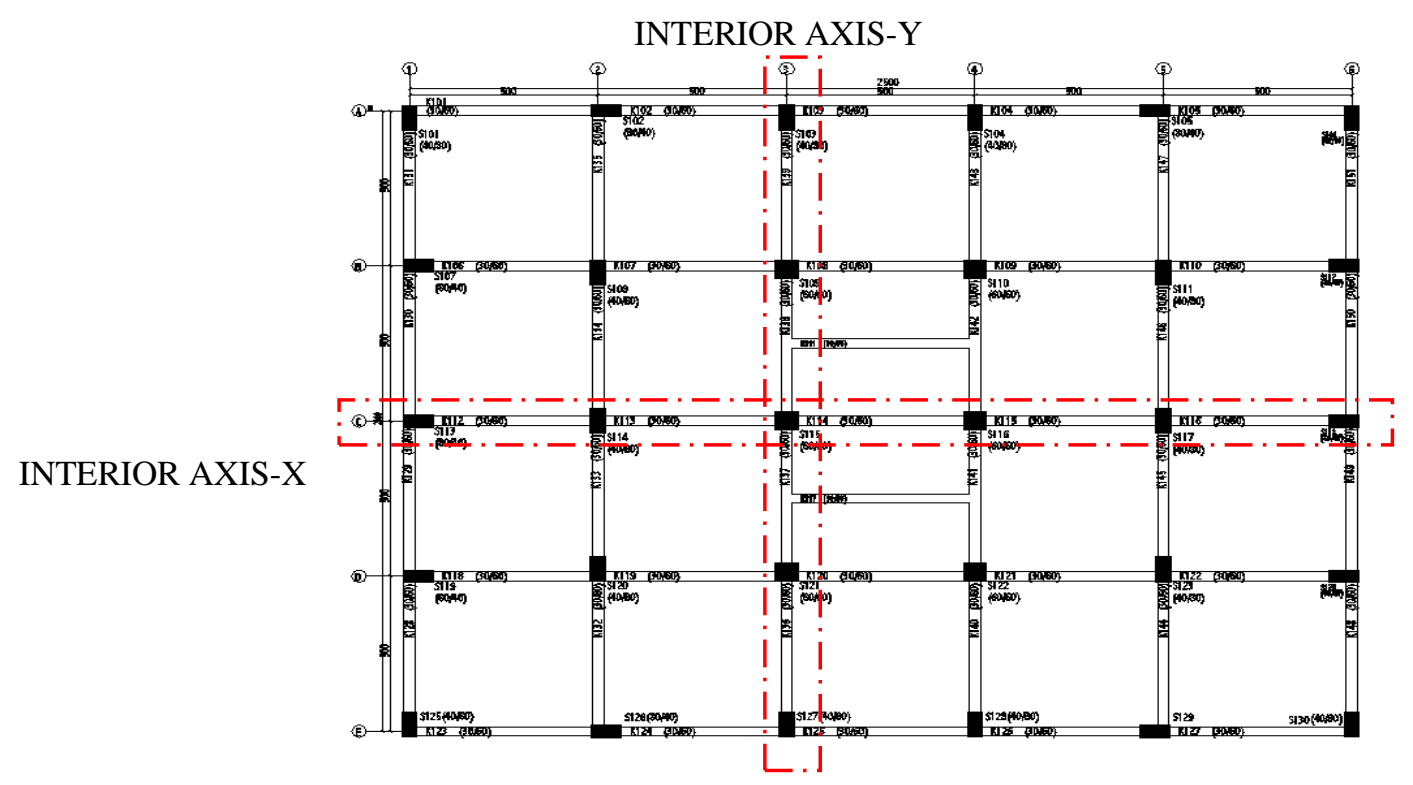

Fig.1. Plan view of the considered buildings (Selected frame models are also marked.) 
Table 1. The dominant vibration periods in the relevant direction of the models used in the study $\left(\mathrm{T}_{1}\right)$

\begin{tabular}{llllll}
\hline Models & $\mathrm{T}_{1}(\mathrm{~s})$ & Models & $\mathrm{T}_{1}(\mathrm{~s})$ & Models & $\mathrm{T}_{1}(\mathrm{~s})$ \\
\hline 10S-2D-X & 1.37 & 15S-2D-X & 2.11 & 20S-2D-X & 2.35 \\
10S-2D-Y & 1.31 & 15S-2D-Y & 1.97 & 20S-2D-Y & 2.15 \\
10S-3D-X & 1.35 & 15S-3D-X & 1.76 & 20S-3D-X & 1.97 \\
10S-3D-Y & 1.31 & 15S-3D-Y & 1.71 & 20S-3D-Y & 1.87 \\
\hline
\end{tabular}

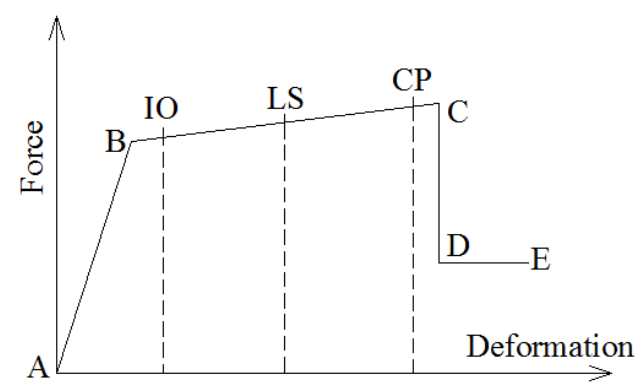

Fig.2. Typical strength-deformation relation

\section{Ground motions}

A total of 12 earthquake records with forward directivity effect were used in the study. Forward directivity produces ground motion which contains large amplitudes and short durations [10-11]. Because of this, acceleration records with forward directivity can cause very serious demand increases in structures near the fault, as they carry relatively large velocity pulse effects $[8,9,12]$. Such acceleration records take part in some sources as earthquakes carrying pulse effect "near source" [13].

Table 2. Earthquake acceleration records used in the study and their characteristics

\begin{tabular}{cccccccc}
\hline No & Earthquake & Date & Station & Component & $\begin{array}{c}\text { PGA } \\
(\mathrm{g})\end{array}$ & $\begin{array}{c}\text { PGV } \\
(\mathrm{mm} / \mathrm{s})\end{array}$ & $\begin{array}{c}\text { Vs30 } \\
(\mathrm{m} / \mathrm{s})\end{array}$ \\
\hline 1 & Cape Men. & 25.04 .1992 & Petrolia & 090 & 0.662 & 897 & 712.8 \\
2 & Duzce & 12.11 .1999 & Bolu & 090 & 0.822 & 621 & 326.0 \\
3 & Erzincan & 13.03 .1992 & Erzincan10 & EW & 0.496 & 643 & 274.5 \\
4 & Imperial V. & 15.10 .1979 & Brawley Air & 315 & 0.220 & 389 & 208.7 \\
5 & Kobe & 16.01 .1995 & Takatori & 090 & 0.616 & 1207 & 256.0 \\
6 & Kocaeli & 17.08 .1999 & Duzce & 270 & 0.358 & 464 & 276.0 \\
7 & Kocaeli & 17.08 .1999 & Gebze & 000 & 0.244 & 503 & 792.0 \\
8 & Landers & 28.06 .1992 & Lucerne & 275 & 0.721 & 976 & 684.9 \\
9 & Loma Pri. & 18.10 .1989 & Los Gatos Lex & 090 & 0.508 & 728 & 1070.3 \\
10 & Morgan Hill & 24.04 .1984 & C. Lake Dam & 285 & 1.298 & 808 & 597.1 \\
11 & Northridge & 17.01 .1994 & Newhall F. & 360 & 0.590 & 972 & 269.1 \\
12 & Northridge & 17.01 .1994 & Sylmar Ol & 090 & 0.604 & 782 & 440.5 \\
\hline
\end{tabular}

The characteristics of earthquake records used in this study are given in Table 2 [14]. Although there is a limited number of records with forward directivity in the literature, ground motion records with considerably large PGA band have been used. Elastic acceleration spectrum for the 5\% damping ratio of the selected records are given in Figure 3. In addition, the average of acceleration records and response spectrum provided in Turkish Earthquake Code-2007 according to design earthquake with $10 \%$ probability of exceedance in 50 years for $\mathrm{Z} 3$ type soil was plotted. Despite the fact that the 
selected records have a very broad scatter, it seems that it is very close to the spectrum plotted according to TEC-2007.



Fig.3. Elastic acceleration spectrum for 5\% damping of earthquake acceleration records used in the study

\section{Evaluation seismic demand}

Seismic demand estimates of 288 linear and nonlinear time history analyses are compared. Building models used in the study are labeled as number of floor, type of model (2D or 3D), type of behavior (L: linear or N: nonlinear), and direction taken into account for analysis. For example, 10S-2DL-X and 10S-2DN-X represent the $\mathrm{X}$-direction analysis result of a 10-storey two-dimensional linear and nonlinear model, respectively. Roof level displacement and interstory drift demands are used as seismic evaluation parameters.

Roof displacements are normalized by building height and called "roof drift ratio" while interstory displacement demands are normalized by story heights and called "interstory drift ratio". Roof and interstory drift ratio demands are provided Tables 3 and 4, respectively.

Table 3. Roof drift ratio demands of 10-, 15- and 20-storey linear building models (\%)

\begin{tabular}{|c|c|c|c|c|c|c|c|c|c|c|c|c|}
\hline \multirow{3}{*}{ Earthquake } & \multicolumn{4}{|c|}{ 10-storey building } & \multicolumn{4}{|c|}{ 15-storey building } & \multicolumn{4}{|c|}{ 20-storey building } \\
\hline & \multicolumn{2}{|c|}{ 2D-L } & \multicolumn{2}{|c|}{ 3D-L } & \multicolumn{2}{|c|}{ 2D-L } & \multicolumn{2}{|c|}{ 3D-L } & \multicolumn{2}{|c|}{ 2D-L } & \multicolumn{2}{|c|}{ 3D-L } \\
\hline & $\mathrm{X}$ & $\mathrm{Y}$ & $\mathrm{X}$ & $\mathrm{Y}$ & $\mathrm{X}$ & $\mathrm{Y}$ & $X$ & $\mathrm{Y}$ & $X$ & $\mathrm{Y}$ & $X$ & $\mathrm{Y}$ \\
\hline Cap-Pet090 & 0.16 & 0.16 & 0.15 & 0.15 & 0.09 & 0.09 & 0.09 & 0.09 & 0.07 & 0.07 & 0.06 & 0.07 \\
\hline Dzc-Bolu090 & 1.03 & 1.05 & 1.03 & 1.05 & 0.92 & 0.88 & 0.55 & 0.52 & 0.54 & 0.61 & 0.67 & 0.63 \\
\hline Erz-Ew & 0.89 & 0.86 & 0.88 & 0.86 & 1.18 & 1.03 & 0.61 & 0.58 & 0.93 & 0.82 & 0.77 & 0.71 \\
\hline Impv & 0.50 & 0.46 & 0.49 & 0.46 & 0.36 & 0.38 & 0.31 & 0.32 & 0.25 & 0.28 & 0.28 & 0.29 \\
\hline Kobe-Tak090 & 3.01 & 3.31 & 3.12 & 3.28 & 2.82 & 2.47 & 1.78 & 1.67 & 2.02 & 2.15 & 1.86 & 1.80 \\
\hline Koc- & 1.44 & 1.32 & 1.39 & 1.31 & 1.05 & 1.04 & 0.78 & 0.76 & 0.77 & 0.83 & 0.80 & 0.77 \\
\hline Koc- & 0.34 & 0.28 & 0.32 & 0.28 & 0.29 & 0.28 & 0.23 & 0.24 & 0.28 & 0.23 & 0.20 & 0.21 \\
\hline Land & 1.09 & 1.00 & 1.07 & 1.02 & 1.06 & 0.92 & 0.72 & 0.69 & 0.91 & 0.84 & 0.70 & 0.65 \\
\hline Lex090 & 1.48 & 1.40 & 1.45 & 1.40 & 1.33 & 1.22 & 0.96 & 0.92 & 1.04 & 0.99 & 0.91 & 0.87 \\
\hline Mo & 0.95 & 0.98 & 0.97 & 0.99 & 0.60 & 0.62 & 0.57 & 0.57 & 0.41 & 0.46 & 0.46 & 0.47 \\
\hline Nortl & 2.00 & 1.86 & 1.96 & 1.86 & 1.19 & 1.27 & 1.02 & 0.99 & 0.88 & 0.94 & 0.95 & 0.96 \\
\hline Northr-Syl090 & 1.05 & 1.07 & 1.07 & 1.05 & 1.59 & 1.39 & 0.81 & 0.73 & 1.36 & 1.19 & 1.04 & 0.94 \\
\hline $\operatorname{Max}$ & 3.01 & 3.31 & 3.12 & 3.28 & 2.82 & 2.47 & 1.78 & 1.67 & 2.02 & 2.15 & 1.86 & 1.80 \\
\hline Mir & 0.16 & 0.16 & 0.15 & 0.15 & 0.09 & 0.09 & 0.09 & 0.09 & 0.07 & 0.07 & 0.06 & 0.07 \\
\hline Average & 1.16 & 1.14 & 1.16 & 1.14 & 1.04 & 0.97 & 0.70 & 0.67 & 0.79 & 0.78 & 0.72 & 0.70 \\
\hline
\end{tabular}


Table 4. Interstory drift ratio demands of 10-, 15- and 20-storey linear building models (\%)

\begin{tabular}{lcccccccccccc}
\hline & \multicolumn{4}{c}{ 10-storey building } & \multicolumn{4}{c}{ 15-storey building } & \multicolumn{3}{c}{ 20-storey building } \\
\cline { 2 - 14 } & \multicolumn{2}{c}{ 2D-L } & \multicolumn{3}{c}{ 3D-L } & \multicolumn{2}{c}{ 2D-L } & \multicolumn{3}{c}{ 3D-L } & \multicolumn{3}{c}{ 2D-L } & 3D-L \\
\cline { 2 - 14 } & $\mathrm{X}$ & $\mathrm{Y}$ & $\mathrm{X}$ & $\mathrm{Y}$ & $\mathrm{X}$ & $\mathrm{Y}$ & $\mathrm{X}$ & $\mathrm{Y}$ & $\mathrm{X}$ & $\mathrm{Y}$ & $\mathrm{X}$ & $\mathrm{Y}$ \\
\hline Cap-Pet090 & 0.37 & 0.35 & 0.31 & 0.29 & 0.33 & 0.28 & 0.22 & 0.27 & 0.23 & 0.21 & 0.17 & 0.16 \\
Dzc-Bolu090 & 1.37 & 1.48 & 1.42 & 1.47 & 1.46 & 1.07 & 0.94 & 0.96 & 1.22 & 1.07 & 0.94 & 0.82 \\
Erz-Ew & 1.20 & 1.18 & 1.18 & 1.17 & 1.85 & 1.82 & 1.12 & 0.94 & 1.39 & 1.51 & 1.34 & 1.19 \\
Impvall-Bra315 & 0.64 & 0.57 & 0.62 & 0.58 & 0.56 & 0.52 & 0.53 & 0.53 & 0.46 & 0.42 & 0.38 & 0.40 \\
Kobe-Tak090 & 3.93 & 4.54 & 4.20 & 4.49 & 3.87 & 3.43 & 2.44 & 2.36 & 2.58 & 2.72 & 2.60 & 2.31 \\
Koc-Dzc270 & 1.78 & 1.73 & 1.79 & 1.73 & 1.63 & 1.66 & 1.13 & 1.10 & 1.11 & 1.20 & 1.20 & 1.10 \\
Koc-Gbz000 & 0.51 & 0.43 & 0.49 & 0.43 & 0.48 & 0.43 & 0.41 & 0.38 & 0.45 & 0.33 & 0.33 & 0.35 \\
Landers-Lcn275 & 1.49 & 1.56 & 1.50 & 1.23 & 1.43 & 1.28 & 1.01 & 0.81 & 1.35 & 1.05 & 0.69 & 0.60 \\
Lomap-Lex090 & 1.85 & 1.86 & 1.87 & 1.84 & 1.80 & 1.67 & 1.36 & 1.31 & 1.48 & 1.37 & 1.18 & 1.12 \\
Morgan-Cyc285 & 1.37 & 1.47 & 1.38 & 1.43 & 1.74 & 1.27 & 1.27 & 1.10 & 1.32 & 1.16 & 0.95 & 0.93 \\
Northr-Nwh360 & 2.69 & 2.66 & 2.68 & 2.69 & 2.09 & 1.70 & 1.71 & 1.48 & 1.40 & 1.47 & 1.42 & 1.34 \\
Northr-Sy1090 & 1.55 & 1.45 & 1.52 & 1.45 & 2.11 & 1.81 & 1.08 & 1.00 & 2.00 & 1.62 & 1.33 & 1.21 \\
\hline Maximum & 3.93 & 4.54 & 4.20 & 4.49 & 3.87 & 3.43 & 2.44 & 2.36 & 2.58 & 2.72 & 2.60 & 2.31 \\
Minimum & 0.37 & 0.35 & 0.31 & 0.29 & 0.33 & 0.28 & 0.22 & 0.27 & 0.23 & 0.21 & 0.17 & 0.16 \\
Average & 1.56 & 1.61 & 1.58 & 1.57 & 1.61 & 1.41 & 1.10 & 1.02 & 1.25 & 1.18 & 1.04 & 0.96 \\
\hline
\end{tabular}

Roof drift ratios of each building subjected to 12 earthquake records for linear elastic analyses are plotted in Figure 4. It is obvious that 10-storey models have higher scatters for both $2 \mathrm{D}$ and $3 \mathrm{D}$ models. The comparison of 3D and 2D models shown in Figures $4 \mathrm{a}$ and $4 \mathrm{~b}$ clearly points out that the $2 \mathrm{D}$ models have higher scatters. The ratios of maximum and minimum roof drifts are 21.6, 31.3 and 30.3 for 10-, 15- and 20-storey buildings, respectively. The difference in demands is an indication of different damage levels caused by ground motion records on the same buildings.

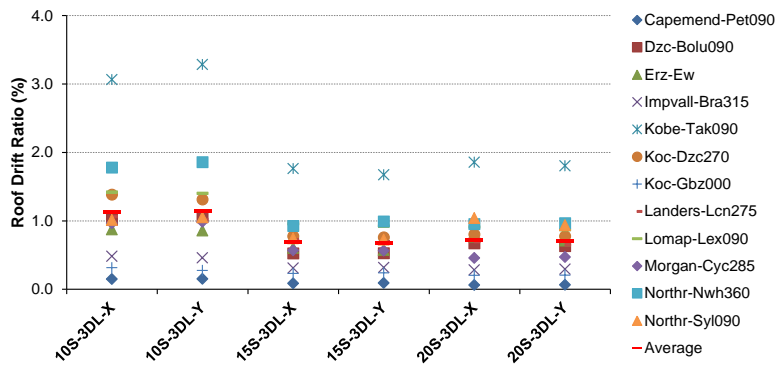

a)

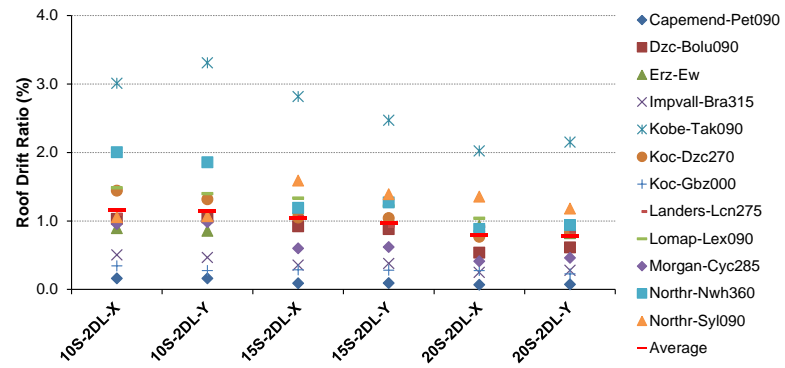

b)

Fig.4. Roof drift ratios of 10-, 15- and 20-storey buildings as linear modelled 3D and 2D (\%)

When the average roof drift ratios are considered, the highest seismic risk is seen in 10-storey buildings. As shown in Figure 5, the spectral acceleration values corresponding to the period values of 10-storey buildings are higher than that of the other buildings in most of earthquake records, especially for strong ones (for example: Kobe-Tak090, Northr-Nwh360, Lomap-Lex090). The higher seismic acceleration demand for 10-storey buildings explains their higher displacement demands. 




Fig.5. The spectral acceleration values corresponding to the period values of 10-, 15- and 20- storey buildings

Figure 6 plots interstory drift ratios of each building subjected to 12 earthquake records for linear elastic analyses. The scatter in 2D models is more apparent than that of 3D models. Among the building sets, the highest scatter for the interstory drifts is observed in the 10-storey buildings.

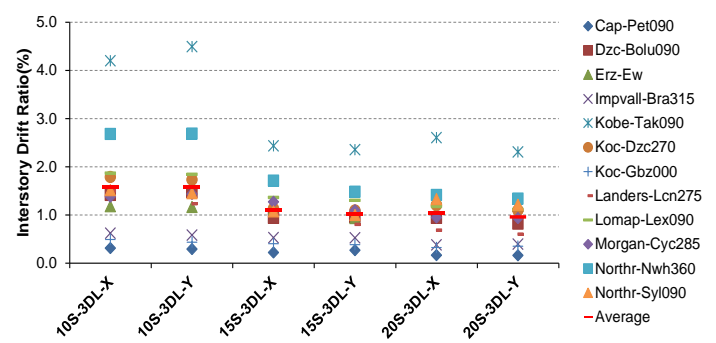

a)



b)

Fig.6. Interstory drift ratios of 10-, 15- and 20-storey buildings as linear modelled 3D and 2D (\%)

Figure 7 compares the average roof and interstory drift ratios of 2D and 3D models to see how 2D linear models reflect 3D linear models. The figure obviously indicates that the 2D linear models of 10 -storey buildings perfectly represent their 3D models. Although the 2D models of 20 -storey models are quite reasonable, the 2D models of 15-storey estimate about $40 \%$ higher demands compared to the 3D models. The comparison of 2D and 3D model estimates obviously shows that the 2D linear models reflect their 3D models for 10- and 20-storey buildings. However, it is difficult to say similar observation for 15 -storey buildings.



a)



b)

Fig.7. Comparison of roof and interstory drift ratios of 10-, 15- and 20-storey buildings for linear 2D and $3 \mathrm{D}$ models 
The floors at which the maximum interstory drift ratios (IDR) were determined for linear 2D and 3D models of 10-, 15- and 20-storey buildings. In this context, primarily the models were represented by 5 -story groups and then the frequency of occurrence for the floor where the maximum IDR occurs is calculated in percent as shown in Figure 8. These values were given as the ratio that the number of occurrences of the maximum relative displacement in the mentioned group to the number of the earthquake records used. Figure 8 illustrates that the 2D and 3D models have similar results indicating good representation of 2D models for their 3D models. When the buildings are evaluated separately, it is seen that the maximum IDR is concentrated in the lower floors of the 10-story buildings, in the middle floors of the 15-story buildings, and in the lower and upper floors of the 20story buildings. The maximum IDR observed at the upper stories for the buildings with no shear walls can be explained with the reduction in column sizes at the upper stories, the decrease in effective section stiffness due to lower column axial loads and forward directivity effect of the ground motion records used in the study $[8,9]$.

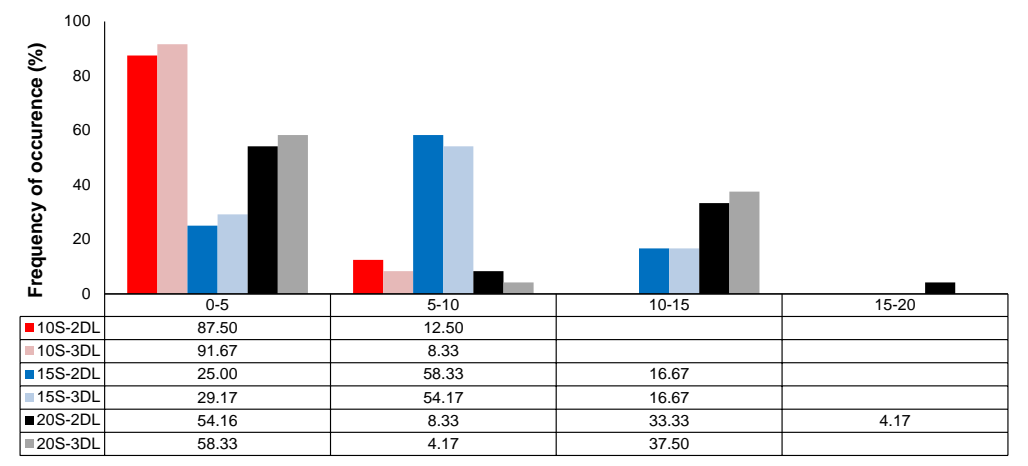

Fig.8. Location of maximum interstory drift ratio for linear 10-, 15- and 20-storey building models

The results of linear and nonlinear time history dynamic analyses are compared for the roof and interstory drift ratios in order to visualize success of linear models in estimating nonlinear demands of RC buildings. Tables 5 and 6 lists nonlinear roof and interstory drift ratio demands for 2D and 3D models. Figure 9a compares the average roof drift ratio of linear and nonlinear models. The average roof drift demands obtained with linear models are normalized by that obtained using corresponding nonlinear models. It is obvious that linear models provide higher demand estimates than their corresponding nonlinear models. The $2 \mathrm{D}$ linear 10-storey building model represents reasonably well its nonlinear model while the 3D linear 15- and 20-storey building models provides better demand estimates. It should be kept in mind that the dominant vibration periods of 2D and 3D models of 10storey building are very close while there are differences in dominant vibration periods of 2D and 3D models of 15- and 20-storey buildings. The better representation of nonlinear model for 10-storey buildings can be attributed to having closer vibration periods. Similar trends are also observed for the interstory drift ratios as seen in Figure $9 b$.

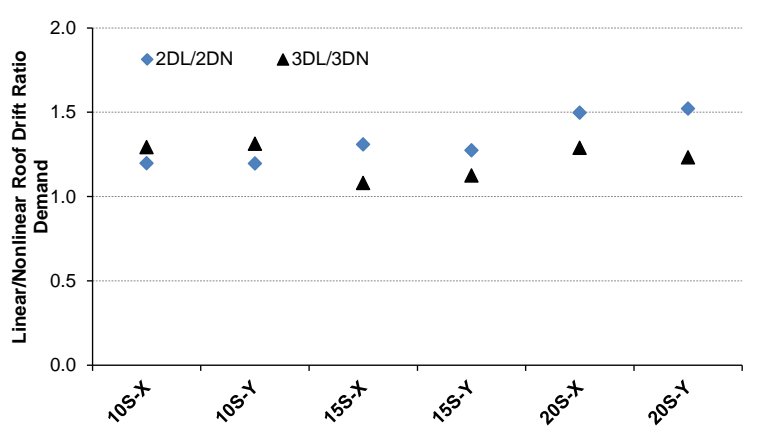

a)



b)

Fig.9. Comparison of average roof and interstory drift ratio demands for linear and nonlinear models 
The estimates of 2D and 3D linear and 2D nonlinear models were also compared to that of 3D nonlinear model in order to visualize success of linear and 2D nonlinear models in seismic demand estimates of RC buildings as shown in Figure 11. It is obvious that the 2D linear models gives higher demand estimates having 30 to $50 \%$ higher estimates compared to the $3 \mathrm{D}$ nonlinear models. In general, 2D nonlinear models are the best representation of 3D nonlinear models.

Table 5. Roof drift ratio demands of 10-, 15- and 20-storey nonlinear building models (\%)

\begin{tabular}{|c|c|c|c|c|c|c|c|c|c|c|c|c|}
\hline \multirow{3}{*}{ Earthquake } & \multicolumn{4}{|c|}{ 10-storey building } & \multicolumn{4}{|c|}{15 -storey building } & \multicolumn{4}{|c|}{ 20-storey building } \\
\hline & \multicolumn{2}{|c|}{$2 \mathrm{D}-\mathrm{N}$} & \multicolumn{2}{|c|}{$3 \mathrm{D}-\mathrm{N}$} & \multicolumn{2}{|c|}{$2 \mathrm{D}-\mathrm{N}$} & \multicolumn{2}{|c|}{$3 \mathrm{D}-\mathrm{N}$} & \multicolumn{2}{|c|}{ 2D-N } & \multicolumn{2}{|c|}{$3 \mathrm{D}-\mathrm{N}$} \\
\hline & $\mathrm{X}$ & $\mathrm{Y}$ & $\mathrm{X}$ & $\mathrm{Y}$ & $\mathrm{X}$ & $\mathrm{Y}$ & $\mathrm{X}$ & $\mathrm{Y}$ & $\mathrm{X}$ & $\mathrm{Y}$ & $\mathrm{X}$ & $\mathrm{Y}$ \\
\hline Cap-Pet090 & 0.16 & 0.16 & 0.15 & 0.16 & 0.09 & 0.09 & 0.09 & 0.09 & 0.07 & 0.08 & 0.06 & 0.07 \\
\hline Dzc-Bolu090 & 0.62 & 0.68 & 0.66 & 0.75 & 0.64 & 0.61 & 0.54 & 0.50 & 0.32 & 0.29 & 0.45 & 0.43 \\
\hline Erz-Ew & 0.92 & 1.02 & 0.88 & 0.84 & 0.88 & 0.85 & 0.60 & 0.60 & 0.51 & 0.52 & 0.62 & 0.60 \\
\hline Impvall- & 0.43 & 0.35 & 0.46 & 0.39 & 0.34 & 0.35 & 0.31 & 0.30 & 0.24 & 0.23 & 0.26 & 0.28 \\
\hline Kobe-Tak090 & 1.41 & 1.39 & 1.70 & 1.95 & 1.19 & 1.18 & 1.09 & 1.03 & 0.80 & 0.78 & 0.87 & 0.90 \\
\hline Koc-Dzc & 1.24 & 1.11 & 1.18 & 0.87 & 0.69 & 0.71 & 0.76 & 0.74 & 0.41 & 0.46 & 0.52 & 0.62 \\
\hline Koc-Gbz000 & 0.34 & 0.27 & 0.32 & 0.21 & 0.29 & 0.28 & 0.24 & 0.24 & 0.19 & 0.23 & 0.20 & 0.21 \\
\hline $\operatorname{Lcn} 275$ & 1.11 & 1.07 & 1.07 & 0.95 & 1.12 & 0.94 & 0.60 & 0.57 & 1.16 & 0.77 & 0.81 & 0.65 \\
\hline Loma & 1.68 & 1.54 & 1.19 & 1.20 & 1.11 & 1.11 & 0.99 & 0.57 & 0.67 & 0.80 & 0.78 & 0.84 \\
\hline Morgan-Cyc & 0.93 & 1.12 & 0.87 & 0.88 & 0.59 & 0.61 & 0.57 & 0.56 & 0.44 & 0.46 & 0.44 & 0.46 \\
\hline Northr-Nwh360 & 1.18 & 1.11 & 0.85 & 0.86 & 1.13 & 1.08 & 0.84 & 0.83 & 0.82 & 0.75 & 0.79 & 0.76 \\
\hline Northr-Sy1090 & 1.57 & 1.56 & 0.89 & 0.92 & 0.88 & 0.81 & 0.95 & 0.94 & 0.58 & 0.51 & 0.61 & 0.63 \\
\hline Maximum & 1.68 & 1.56 & 1.70 & 1.95 & 1.19 & 1.18 & 1.09 & 1.03 & 1.16 & 0.80 & 0.87 & 0.90 \\
\hline Minimum & 0.16 & 0.16 & 0.15 & 0.16 & 0.09 & 0.09 & 0.09 & 0.09 & 0.07 & 0.08 & 0.06 & 0.07 \\
\hline Average & 0.97 & 0.95 & 0.85 & 0.83 & 0.75 & 0.72 & 0.63 & 0.58 & 0.52 & 0.49 & 0.53 & 0.54 \\
\hline
\end{tabular}

Table 6. Interstory drift ratio demands of 10-, 15- and 20-storey nonlinear building models (\%)

\begin{tabular}{lcccccccccccc}
\hline & \multicolumn{4}{c}{ 10-storey building } & \multicolumn{4}{c}{ 15-storey building } & \multicolumn{3}{c}{ 20-storey building } \\
\cline { 2 - 14 } & \multicolumn{2}{c}{ 2D-N } & \multicolumn{2}{c}{ 3D-N } & \multicolumn{2}{c}{ 2D-N } & \multicolumn{3}{c}{ 3D-N } & \multicolumn{2}{c}{ 2D-N } & 3D-N \\
\cline { 2 - 15 } & $\mathrm{X}$ & $\mathrm{Y}$ & $\mathrm{X}$ & $\mathrm{Y}$ & $\mathrm{X}$ & $\mathrm{Y}$ & $\mathrm{X}$ & $\mathrm{Y}$ & $\mathrm{X}$ & $\mathrm{Y}$ & $\mathrm{X}$ & $\mathrm{Y}$ \\
\hline Cap-Pet090 & 0.37 & 0.35 & 0.31 & 0.31 & 0.33 & 0.29 & 2.53 & 2.93 & 0.17 & 0.19 & 0.16 & 0.16 \\
Dzc-Bolu090 & 1.52 & 1.27 & 1.22 & 1.38 & 1.67 & 1.56 & 1.21 & 1.24 & 0.85 & 0.74 & 1.02 & 0.94 \\
Erz-Ew & 1.70 & 1.66 & 1.52 & 1.34 & 1.90 & 1.91 & 1.45 & 1.38 & 1.30 & 1.39 & 1.45 & 1.45 \\
Impvall-Bra315 & 0.62 & 0.54 & 0.63 & 0.58 & 0.60 & 0.57 & 0.53 & 0.52 & 0.48 & 0.39 & 0.38 & 0.39 \\
Kobe-Tak090 & 2.37 & 2.08 & 2.63 & 3.11 & 2.34 & 2.37 & 2.48 & 2.33 & 1.83 & 1.52 & 1.45 & 1.63 \\
Koc-Dzc270 & 1.99 & 1.63 & 1.86 & 1.45 & 1.42 & 1.52 & 1.43 & 1.44 & 0.85 & 0.85 & 0.86 & 1.02 \\
Koc-Gbz000 & 0.56 & 0.45 & 0.51 & 0.29 & 0.49 & 0.43 & 0.40 & 0.38 & 0.48 & 0.33 & 0.36 & 0.36 \\
Landers-Lcn275 & 1.77 & 1.71 & 1.73 & 1.58 & 1.35 & 1.21 & 0.97 & 0.98 & 5.98 & 2.60 & 3.55 & 1.54 \\
Lomap-Lex090 & 2.55 & 2.19 & 2.05 & 1.93 & 2.39 & 2.41 & 1.91 & 0.98 & 1.48 & 1.57 & 1.29 & 1.46 \\
Morgan-Cyc285 & 1.80 & 1.81 & 1.55 & 1.50 & 1.30 & 1.34 & 1.17 & 1.21 & 1.18 & 0.98 & 0.88 & 0.85 \\
Northr-Nwh360 & 1.98 & 1.60 & 1.59 & 1.58 & 2.37 & 2.42 & 1.67 & 1.73 & 2.86 & 2.00 & 1.85 & 1.41 \\
Northr-Sy1090 & 2.25 & 2.37 & 1.49 & 1.39 & 2.17 & 1.89 & 1.65 & 1.71 & 2.60 & 1.75 & 2.29 & 1.45 \\
\hline Maximum & 2.55 & 2.37 & 2.63 & 3.11 & 2.39 & 2.42 & 2.53 & 2.93 & 5.98 & 2.60 & 3.55 & 1.63 \\
Minimum & 0.37 & 0.35 & 0.31 & 0.29 & 0.33 & 0.29 & 0.40 & 0.38 & 0.17 & 0.19 & 0.16 & 0.16 \\
Average & 1.62 & 1.47 & 1.42 & 1.37 & 1.53 & 1.49 & 1.45 & 1.40 & 1.67 & 1.19 & 1.30 & 1.06 \\
\hline
\end{tabular}




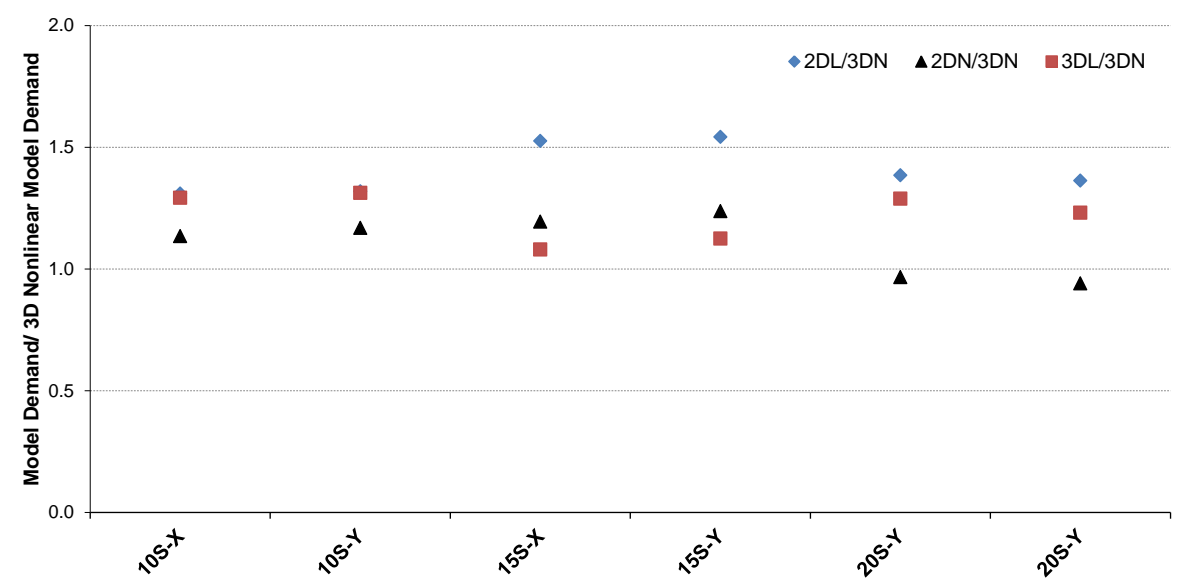

Fig.11. The ratio of displacement demands obtained from models to 3D nonlinear displacement demand

\section{Observations and results}

This study compared displacement demands obtained from linear and nonlinear time history analyses of $2 \mathrm{D}$ and 3D models to investigate how 2D models reflect 3-D models. The estimates of 2D and 3D linear and 2D nonlinear models were also compared to that of 3D nonlinear model in order to visualize success of linear and 2D nonlinear models in seismic displacement estimates of RC buildings. A total of 288 dynamic analyses were performed with 12 different earthquakes records taking into account the two principal directions of 10-, 15- and 20-storey buildings. The observations and outcomes are summarized below:

$>$ The roof and interstory drift demands illustrate that the 10-storey building models have the highest demand ratios and scatter. The comparison of 3D and 2D models clearly points out that the $2 \mathrm{D}$ models have higher scatters.

$>$ The comparison of average roof and interstory drift ratios for 2D and 3D models obviously indicates that the 2D linear models reflects their 3D models reasonably well for 10 - and 20-storey buildings. However, it is difficult to say similar observation for 15storey buildings. The differences between $2 \mathrm{D}$ and 3D models in demands estimates are about $0 \%, \% 50$ and $12 \%$ for 10-, 15- and 20-storey buildings, respectively.

$>$ The maximum interstory drift ratios were concentrated at lower floors of 10-storey buildings, at the middle floors of 15-storey buildings, and at the lower or upper floors of 20 -storey buildings. This observation indicates that as the number of storey increases, it is difficult to estimate location of the floor with maximum interstory drift.

$>$ The results of linear and nonlinear time history dynamic analyses are compared for the roof and interstory drift ratios in order to visualize success of linear models in estimating nonlinear demands of RC buildings. The average roof and interstory drift demands obtained with linear models are normalized by that obtained using corresponding nonlinear models. The results show that linear models provide higher demand estimates than their corresponding nonlinear models. The 2D linear 10-storey building model represents reasonably well its nonlinear model while the 3D linear 15- and 20-storey building models provides better demand estimates. It should be kept in mind that the dominant vibration periods of $2 \mathrm{D}$ and $3 \mathrm{D}$ models of 10 -storey building are very close while there are differences in dominant vibration periods of $2 \mathrm{D}$ and $3 \mathrm{D}$ models of 15 - and 20 -storey buildings. The better representation of nonlinear model for 10-storey buildings can be attributed to having closer vibration periods. 
In general, the outcomes of the current study imply that 2D representation of 3D models needs careful modelling. The buildings are usually designed according to the related earthquake code considering both gravity and seismic loads. Then, an interior frame is used for $2 \mathrm{D}$ modelling. The periods of $3 \mathrm{D}$ and $2 \mathrm{D}$ models need to be closer in order to have proper representation. Another observation is that the $2 \mathrm{D}$ linear elastic models do not properly represent the $3 \mathrm{D}$ nonlinear models. Thus, it is recommended to use 3D models when linear modelling is preferred. Since the 2D nonlinear models represent reasonably well their 3D nonlinear ones, the $2 \mathrm{D}$ modelling can be preferred for the buildings with no irregularity due to extensive labor and time required for 3D nonlinear models.

\section{References}

[1] SAP2000 V-19 CSI. Integrated finite element analysis and design of structures basic analysis reference manual, Berkeley, USA.

[2] DBYBHY-2007, Deprem bölgelerinde yapılacak binalar hakkında yönetmelik, Bayındırlık ve İskan Bakanlığ1, Ankara, 2007.

[3] FEMA-356, Prestandard and commentary for seismic rehabilitation of buildings, Report No. FEMA-356, Federal Emergency Management Agency, Washington, D.C., 2000.

[4] Mander, J.B., Priestley, M.J.N. and Park, R., Theoretical stress-strain model for confined concrete. ASCE, 114(8), 1804-1826, 1988.

[5] İnel, M., Özmen, Hayri B., Effects of plastic hinge properties in nonlinear analysis of reinforced concrete building, Engineering Structures, 28(11):1494-1502, 2006.

[6] SEMAp, Sarg1 etkisi modelleme analiz program1, 2008, Tubitak proje no: 105M024.

[7] Fardis, M.N., Biskinis D.E., Deformation of RC members, as controlled by flexure or shear, In: proceedings of the international symposium honoring Shunsuke Otani on performance-based engineering for earthquake resistant reinforced concrete structures, 2003.

[8] İnel, M., Çelik, S., Özmen, Hayri B., Önür, Ö., İleri yönlenmeli deprem kayıtları etkisindeki mevcut betonarme binaların deplasman taleplerinin doğrusal elastik olmayan zaman tanım alanında analizle değerlendirilmesi, Yedinci Ulusal Deprem Mühendisliği Konferansı, İstanbul, Türkiye, 2011.

[9] İnel, M., Önür, Ö., Özmen, Hayri B., Çelik, S., İleri yönlenmeli deprem kayıtları etkisindeki mevcut betonarme binaların deplasman taleplerinin doğrusal elastik zaman tanım alanında analizle değerlendirilmesi, Yedinci Ulusal Deprem Mühendisliği Konferansı, İstanbul, Türkiye, 2011.

[10] Bray, Jonathan D., Rodriguez-Marek, A., Characterization of forward-directivity ground motions in the near-fault region, Soil Dynamics and Earthquake Engineering, 815-828, 2004.

[11] Cao, V.V. and Ronagh, H.R., Correlation between seismic parameters of pulse-type motions and damage indices of low-rise reinforced concrete frames, Soil Dynamics and Earthquake Engineering, 66, 102-112, 2014. 
[12] Sommerville, P.G., Engineering characteristics of near fault ground motion, SMIP Seminar Proceedings, California, 1989.

[13] Sommerville, P.G., Smith, N.F., Graves, R.W. and Abrahamson N.A, Modifications of empirical strong ground motion attenuation relations to include the amplitude and duration effects of rupture directivity, Seismological Resarch Letters, 68(1), 1997.

[14] PEER, http://peer.berkeley.edu 